\title{
MUSTARD, SPIDERWEB, PUDDLES, COMMA AND DRAGONFLY
}

BERNIE GOLLOP, 2202 York Ave., Saskatoon, SK. S7J 1J1, and MIKE GOLLOP, 51 Welker Cresc., Saskatoon, SK. S7H 3M3

In the course of butterfly and dragonfly surveys in southwestern Saskatchewan from 1 to 4 July 1996, we made the following mini-observations.

Mustard: An exceptionally thick band of mustard stretched for maybe a mile at water's edge along the south shore of the South Saskatchewan River west of Highway 4 in Saskatchewan Landing Provincial Park on the 1st. Because butterflying had been poor along the trail, BG decided to check the mustard, not noted as butterfly habitat. However, just over an hour in three patches of this sun-drenched stand of yellow we turned up nine species: 10 Western Whites, 8 Common Ringlets, 5 Common Checkered and 2 Garita Skippers, 4 Milbert's Tortoiseshells, 3 Purplish Coppers, 2 sulphurs, a White Admiral, and, most surprisingly, that denizen of shady aspen groves, a Mourning Cloak, feeding leisurely from one flower to another. ${ }^{\text {" }}$

Spiderweb: On the 2nd, beside the Cypress Hills Provincial Park (CHPP) lagoon, was a seemingly perfect orb web about $2 \mathrm{ft}$. above the ground but, instead of being in the usual vertical plane, it was horizontal - perfectly horizontal.

Puddles - at least some puddles are well known as butterfly habitat. One on the trail of a logged opening on the Boiler Creek Road, CHPP, at- tracted seven species in about 30 minutes on the 2nd: White Admiral, Greenish and Western Tailed Blues, Meadow Fritillary, Western Pine Elfin, skipper, sulphur and crescent. There were never more than six butterflies sipping the mud at one time. On the same day, where Boiler Creek flowed shallowly across the road, there were at least 15 crescents, 3 Greenish and 4 Western Tailed Blues at 3 p.m. But the best Cypress Hills puddle we have found was on 15 August 1995 where the west road crosses Sucker Creek. In a 10-minute period, we saw 11 species: 15 Meadow, 10 Mormon and 2 Titania Fritillaries, 2 crescents, 2 Peck's Skippers, and singles of Mustard White, Mourning Cloak, Satyr and Green commas, Common Wood-Nymph and ringlet.

Comma: Along Belanger Creek, CHPP, on the 2nd, MG noted a particularly territorial Satyr Comma: I first spotted it chasing a Mourning Cloak back and forth along a cutline in the coniferous forest. The comma then landed on a branch about $8 \mathrm{ft}$. up in an aspen. Almost immediately it spotted me and fluttered around my head, suggesting I shove off. Deciding that wasn't working, he returned to his perch but only briefly. Again he saw the Mourning Cloak and was off. In a few minutes, it returned to its branch but not before repeating its earlier message to me 
which I finally got. If the 10 minutes I watched was any indication, this butterfly had a stressful and strenuous day.

Dragonfly: In attempting to catch dragonflies to identify them at Loch Lomond, CHPP, on the 4th, BG spent his time missing nearby individuals. After one unsuccessful swing, the dragonfly in question backed off about a foot beyond the net, hovered and seemed to ask: "Got any better ideas?"

1. Butterfly names are from NORTH AMERICAN BUTTERFLY ASSOCIATION. 1995. Checklist and English names of North American butterflies. Morristown, NJ. 07960

\section{POETRY}

\section{Yr Wylan (THE SEAGULL)}

The fair seagull on the tide,

The very same colour as snow or moonlight,

Your fairness is spotless, A scrap like the sun, glove of the sea, You are light upon the ocean wave, Swift, proud fish-eating bird!

Go there by the anchor, Hand in hand with me, sea-lily.

Like a bright-looking letter,

You are a nun upon the sea-tide.

Girl's praise, she'll have far praise Go to the bend of wall and castle, Look if you can see, seagull, That Eigr on the bright wall.

Say my acceptable words.

May she choose me! Go to the girl.
If she's alone, be bold to greet her, Be clever with the delicate girl, To win her. Say l'll not Live, a gentle fellow, unless I have her.

I love her, cause of all passion.

Oh men! Never did smooth-mouthed

Merlin

Or Taliesin love one more lovely than her, Cypress-like, fought for, under copper hair,

Most beautiful, too proper!

Oh seagull, if you see

The cheek of the loveliest girl in Christendom,

Unless I have the sweetest of greetings, The girl will be my end.

DAFYDD AP GWILYM (fl. $1340-70$ ) translated from Welsh by Twym Morys 